\title{
Immobilization of $\alpha$-Amylase from Locale Bacteria Isolate Bacillus subtilis ITBCCB148 with Carboxymethyl Cellulose (CM-Cellulose)
}

\author{
Yandri (Corresponding author), Devi Susanti, Tati Suhartati \& Sutopo Hadi (Corresponding author) \\ Department of Chemistry, Faculty of Mathematics and Natural Sciences \\ University of Lampung, Bandar Lampung 35145, Indonesia \\ E-mail: yandrias@unila.ac.id; sutopohadi@unila.ac.id
}

Received: December 21, 2011

Accepted: February 8, $2012 \quad$ Published: March 1, 2012

doi:10.5539/mas.v6n3p81

URL: http://dx.doi.org/10.5539/mas.v6n3p81

\begin{abstract}
This paper describes the stability increase of $\alpha$-amylase obtained from Bacillus subtilis ITBCCB 148 by immobilization process using carboxymethyl cellulose (CM-Cellulose) as the immobile matrix. To achieve this aim the enzyme was purified by the following steps: fractionation with ammonium sulphate, dialysis, ion exchange column chromatography with CM-cellulose and molecule filtration column chromatography with Sephadex G-100. The purified enzyme was then immobilized with CM-Cellulose. The result showed that the immobilization with CM-cellulose on $\alpha$-amylase obtained from B. subtilis has successfully increased the thermal stability of the native enzyme. The thermal stabilities of the modified enzyme were increased 3.67 times compared to the native enzyme. The decrease of ki value, the increase of half-life and $\Delta \mathrm{Gi}$ values showed that the modified enzymes were more stable than the native enzyme.
\end{abstract}

Key words: $\alpha$-amylase, Immobilization, CM-cellulose, $B$. subtilis ITBCCB148

\section{Introduction}

Enzymes have widely been used commercially due to their uses as biocatalyst which can work specifically and efficiently. However, there are some weaknesses of enzyme uses in industry such as the instability of the enzymes, the availability and the limited use of the enzyme which cause their use in industrial sector is limited (Chibata, 1978). In order to solve and diminish these weaknesses, the immobilization process was then developed. There are some advantaged after the enzymes were immobilized, they can easily be treated, the activity is easily controlled and can be used repeatedly.

According to Chibata (1978), the immobilization methods were classified into 3 categories: i.e. (i) trapping method; (ii) binding method (adsorption) on the support matrix and (iii) cross-link method. The immobilization of the enzyme with adsorption method can be achieved by a variety of matrices. The chemical bonds formed are hydrogen bond, hydrophob bond and a weak bond, Van der Waals bond, which has less effect to the change of the enzyme conformation physically, so it may be ignored. There are some advantages of using the adsorption method as the immobilized enzyme formed will be more in number than using other immobilization method, since the enzyme is present directly in the surface of the support matrix so the possibility to come across between the enzyme and the substrate will be greater and the complex formed by enzyme and substrate will also be more. The binding in the adsorption method is normally occurred by ionic and covalent bond. The uses of support matrix containing either anionic or cationic exchange residues as immobile matrix has some advantages as the bond formed is relatively stable (Yandri, et al., 2010b).

Some previous researches performed with immobilization and chemical modification have shown that the enzymes obtained have significantly increased their stability against $\mathrm{pH}$ and temperature compared to the native enzyme (Yandri, et al., 2008, 2010a, 2010b; Germain dan Crichton, 1988; Cordt, et al., 1992; Steadman, et al., 1991; Skerker dan Clark, 1987; Rani, et al., 2007; Reshmi, et al., 2007).

Based on the research previously reported, the immobilization process with CM-cellulose was chosen in this research to increase the stability of $\alpha$-amylase which was produced, isolated and purified from local bacteria isolate B. subtilis ITBCCB148. 


\section{Experiment}

\subsection{Materials}

All chemicals used were of high grade (pro analysis) materials. Local bacteria isolate B.subtilis ITBCCB148 was obtained from Microbiology and Fermentation Technology Laboratory, Chemical Engineering Department, Bandung Institute of Technology, Bandung, Indonesia.

\subsection{Research Procedure}

The following research phases were done: the production, isolation, purification and characterization of the native enzyme were based on our previous report (Yandri, et al., 2010a).

\subsection{Activity Test of $\alpha$-amylase and Determination of Protein Content}

Activity of $\alpha$-amylase was determined based on the Iodin method (Fuwa, 1954) and using dinitrosalicylic acid reagent (Mandels, et al., 1976). The protein content was determined based on the method by Lowry et al. (1951).

\subsection{Immobilization of Purified Enzyme with CM-Cellulose (Bolag, et al., 1996)}

To determine the $\mathrm{pH}$ binding, a certain amount of ready stock CM-cellulose was transferred then stabilized at various $\mathrm{pH}$ is using buffer of tris $\mathrm{HCl} 0.1 \mathrm{M}$ with $\mathrm{pH}$ variation of 5, 5.5, 6, 6.5, 7.0, 7.5 and 8.0. 0.5 mL enzyme was then added to each of the solution prepared and eluted with the suitable buffer for each $\mathrm{pH}$ and mixed for 5-10 minutes. The mixture was then left aside to precipitate out the DEAE-Cellulose and then decanted. The activity test was taken on the supernatant, and the protein content was also determined. To know at what $\mathrm{pH}$ the purified enzyme was bound, it was eluted at eluting the bound enzyme by varying $\mathrm{pH}$ 's and based on the ionic strength.

\subsection{Characterization of Enzyme before and after Immobilization}

The characterization of enzyme before and after modification included: determination of optimum $\mathrm{pH}$, kinetic data, and determination of thermal stability.

\subsubsection{Determination of Optimum Temperature of Enzyme before and after Immobilization}

The determination of optimum temperature of enzyme before and after immobilization was done by varying the temperature at $55,60,65,70,75$ and $80^{\circ} \mathrm{C}$.

\subsubsection{Determination of KM dan Vmax Values of Enzyme before and after Immobilization}

The Michaelis-Menten (KM) constant and maximum reaction rate (Vmax) values of enzyme before and after modification were determined by varying the substrate concentration of amylum solution at $0.1,0.2,0.4,0.6,0.8$, 1.0 and $1.25 \%$.

\subsubsection{The Stability Test of Enzyme before and after Immobilization}

The stability of enzyme before and after modification was done based on the known procedure 14 which entailed measuring the residual activity of the enzyme after being incubated for $0,10,20,30,40,50$, and 60 minutes at optimum temperature, where the initial activity of enzyme without heating was given a value of $100 \%$.

\subsubsection{Determination of Half-life $\left(\mathrm{t}^{1} / 2\right), \mathrm{k}_{\mathrm{i}}$ and $\Delta \mathrm{G}_{\mathrm{i}}$}

Determination of ki value (thermal inactivation rate constant) of the native enzyme and the modified enzyme was done using the first order of inactivation kinetics equation (Eq. 1) (Kazan, et al., 1997):

$$
\ln \left(\mathrm{E}_{\mathrm{i}} / \mathrm{E}_{0}\right)=-\mathrm{k}_{\mathrm{i}} \mathrm{t}
$$

Where $E_{i}$ and $E_{0}$ are the activity of the inactivated and initial forms of the enzyme, respectively: $k i$ is the inactivation rate constant of the enzyme and $t$ is the time.

The denaturation energy change ( $\Delta \mathrm{Gi}$ ) of the native and modified enzymes was done using Eq. 2 (Kazan, et al., 1997):

$$
\Delta \mathrm{G}_{\mathrm{i}}=-\mathrm{RT} \ln \left(\mathrm{k}_{\mathrm{i}} \mathrm{h} / \mathrm{k}_{\mathrm{B}} \mathrm{T}\right)
$$

Where ki is the inactivation rate constant of enzyme, $\mathrm{kB}$ is the Boltzmann constant, $\mathrm{h}$ is Planck's constant and $\mathrm{T}$ is the absolute temperature and $\mathrm{R}$ is the universal gas constant.

\section{Results and Discussion}

\subsection{Determination of Optimum Temperature of the Native and Immobilized Enzyme}

The optimum temperature of the native enzyme as shown in Figure 1 was $60{ }^{\circ} \mathrm{C}$, after being immobilized the optimum temperature was increased to $65^{\circ} \mathrm{C}$. The shift of the optimum temperature is due to the steric hindrance caused by matrix support to enzyme molecule, so the enzyme is protected from the effect of heat denaturation. 
The immobilized enzyme requires higher temperature than that of native enzyme in changing the substrate to the products, as also reported previously by some researchers (Kazan, et al., 1997; Francis, et al., 1992; Germain and Crichton, 1988) that chemical modification and immobilization process were able to increase the optimum temperature of the native enzyme after being treated.

The stability of immobilized enzyme at higher temperature was also found better than that of the native enzyme, this condition perhaps the immobilization process cause the rigidity of the immobilized enzyme was also increased, as a result it was resistant against higher temperature.

\subsection{Determination of Enzyme Kinetic Data of the Native and Immobilized Enzymes}

The Lineweaver-Burk equations are shown in Figures 2 and 3, and based on these graphs the values of $\mathrm{V}_{\max }$ and $\mathrm{K}_{\mathrm{M}}$ of the native enzyme were $71.428 \mu \mathrm{mol} / \mathrm{mL} / \mathrm{min}$ and $2.85 \mathrm{mg} / \mathrm{mL}$ substrate, repectively, while for the immobilized enzyme has $\mathrm{V}_{\max }$ and $\mathrm{K}_{\mathrm{M}}$ value of $62.5 \mu \mathrm{mol} / \mathrm{mL} / \mathrm{min}$ and $3.125 \mathrm{mg} / \mathrm{mL}$ substrate, respectively. The decrease of $\mathrm{V}_{\max }$ of the immobilized enzyme was due to the steric hindrance of the insoluble immobile matrix, as a result the interaction of substrate and enzyme was hindered. The increase of $\mathrm{K}_{\mathrm{M}}$ of the immobilized enzyme indicated that the enzyme affinity towards substrate was less compared to the native enzyme.

\subsection{The Enzymatic Conversion of Starch to Glucose Using the Immobilized Enzyme with Repeated Use}

The enzymatic conversion of amylum to glucose using immobilized enzyme in repeated use can be seen in Figure 4. The immobilized enzyme was able to be used in 6 repetitions. In the sixth repeat, the immobile enzyme has residual activity (\%) of $22 \%$. It was active up to the fifth repeat with residual activity (\%) of $39.4 \%$. The decrease of activity in repeated used was due to the physical lost as it was as washed after being used.

\subsection{The Enzyme Thermal Stability of before and after Immobilization}

The residual activities (\%) of native and immobile enzymes were determined by incubating each enzyme at 60 ${ }^{\circ} \mathrm{C}$ for $60 \mathrm{~min}$. At a certain interval time, the activity of each enzyme was determined. The graph of stability of both enzymes is shown in Figure 5. This figure showed residual activity of each enzyme at $60{ }^{\circ} \mathrm{C}, \mathrm{pH} 5.5$ for 60 min. The residual activity (\%) of native enzyme was $0.9 \%$, while the immobile enzyme was $26 \%$. This is because the immobilized enzyme was protected from the outside effect which causes the protein denaturation, so the immobile enzyme was more stable than the native enzyme.

\subsection{The Constant of Thermal Inactivation $\left(k_{i}\right)$, Half-life $\left(t_{1 / 2}\right)$ and the Change of Energy due to Denaturation $\left(\Delta G_{i}\right)$} of Native and Immobilized Enzymes

The constant value of thermal inactivation $\left(\mathrm{k}_{\mathrm{i}}\right)$, half-life $\left(\mathrm{t}_{1 / 2}\right)$ and the change of energy due to denaturation $\left(\Delta \mathrm{G}_{\mathrm{i}}\right)$ of native and immobilized enzymes with CM-cellulose is tabulated in Table 1 . The half-life $\left(t_{1 / 2}\right)$ of immobilized enzyme was increase significantly. According to Stahl (1999) the half-life determines the enzyme stability. In this research there was a big increase of half-life of native enzyme which was 7.875 minutes to 28.875 minutes for the immobilized enzyme.

The data in Table 1 also shows the constant value of thermal inactivation $\left(\mathrm{k}_{\mathrm{i}}\right)$ of native and immobilized enzyme where the stability of the immobilized enzyme was increased 3.67 times compared to the native enzyme. The decrease of $\mathrm{k}_{\mathrm{i}}$ value was an indication of bond formation from $\mathrm{NH}_{2}$ group on the side chain of lysine residue on the surface of the enzyme with immobile matrix. This condition caused the enzyme was less flexible on aqueous solution, as a result the protein unfolding was also less and the enzyme stability was increased (Yang, et al., 1996).

The change of energy due to denaturation $\left(\Delta \mathrm{G}_{\mathrm{i}}\right)$ of native and immobilized enzymes can be seen in Table 1 where the values were 99.95 and $103.53 \mathrm{~kJ} \cdot \mathrm{mol}^{-1}$, respectively. The increase of $\Delta \mathrm{G}_{\mathrm{i}}$ of the immobilized enzyme signifies that the enzyme structure was more rigid, so that the energy required to denature the enzyme was higher. The rigidity of enzyme structure has stronger bond in its molecule, so the enzyme conformation is hard to open and the tertiary structure of the enzyme is more sustained (Yang, et al., 1996).

\section{Conclusions}

The immobilization with CM-cellulose on $\alpha$-amylase obtained from B. subtilis has successfully increased the thermal stability of the native enzyme. This has been shown by the increase of optimum temperature of the immobilized enzyme from 60 to $65{ }^{\circ} \mathrm{C}$. The $\mathrm{K}_{\mathrm{M}}$ value of the immobilized enzyme was higher than the native enzyme, while $V_{\max }$ value of the immobilized enzyme was lower than the native enzyme. After being used 5 times, the activity of the immobilized enzyme still remained 39.4\%. The thermal stabilities of the modified enzyme were increased 3.67 times compared to the native enzyme. The decrease of ki value, the increase of half-life and $\Delta \mathrm{Gi}$ values showed that the immobilized enzymes were more stable than the native enzyme. 


\section{Acknowledgments}

The authors would like to thank The Directorate of Research and Community Services, Directorate General of Higher Education, The Ministry of National Education of Republic of Indonesia that provided funds for this project to be undertaken through the Strategic Research Grant Scheme (Penelitian Hibah Strategis) 2009 with contract number 1896/H26/KU/2009, 1 July 2009.

\section{References}

Bollag, D. M., Rozycki, M. D., \& Edelstein, S. J. (1996). Protein Methods $2^{\text {nd }}$ ed., John Wiley \& Sons, Inc., Publication, New York, 91-93, 232-274.

Chibata, I. (1978). Immobilized Enzymes, Research and Development. Halsted Press Book, New York, 298.

Cordt, S. D., Vanhoof, K., Hu, J., Maesmans, G., Hendrickx, M., \& Tobback, P. (1992). Thermostability of soluble and immobilized a-amylase from Bacillus licheniformis. Biotech. Bioeng., 40, 396-402. http://dx.doi.org/10.1002/bit.260400309

Francis, G. E., Delgado, C., \& Fisher, D. (1992). PEG-modified proteins in Stability of Protein Pharmaceuticals Part B. Plenum Press, New York, 246-247.

Fuwa, H. (1954). A new method for microdetermination of amylase activity by the use of amylose as the substrate. J. Biochem, Tokyo, 41, 583-603.

Germain, P., \& Crichton, R. R. (1988). Characterization of a chemically modified $\beta$-amylase immobilized on porous silica. J. Chem. Tech. Biotechnol., 41, 297-315. http://dx.doi.org/10.1002/jctb.280410406

Kazan, D., Ertan, H., \& Erarslan, A. (1997). Stabilization of Escherichia coli Penicilin G Acylase Against.

Thermal Inactivation by Cross-linking with Dextran Dialdehyde Polymers. Applied Microbiology and Biotechnolgy, 48(2), 191-197. http://dx.doi.org/10.1007/s002530051037

Lowry, O. H., Rosebrough, N. J., Farr, A. L., \& Randall, R. J. (1951). Protein measurment with the Folin phenol reagent. J. Biol. Chem., 193-265.

Mandels, M., Raymond, A., \& Charles, R. (1976). Measurement of saccharifying cellulase, Biotech. Bioeng. Symp., 6, 21-33.

Rani, P., Sharma, M., Kumar, V., \& Pundir, C. S. (2007). Immobilization of amylase onto arylamine glass beads affixed inside a plastic beaker: Kinetic properties and application. Indian J. Biotechnol., 6, 230-233.

Reshmi, R., Sanjay, G., \& Sugunan, S. (2007). Immobilization of $\alpha$-amylase on zirconia: A heterogeneous biocatalyst for starch hydrolysis. Catal. Comm., 8, 393-399. http://dx.doi.org/10.1016/j.catcom.2006.07.009

Skerker, P. S., \& Clark, D. S. (1989). Thermostability of alcohol dehydrogenase: Evidence for distinct subunits with different deactivation properties. Biotech. and Bioeng., 33, 62-71. http://dx.doi.org/10.1002/bit.260330109

Stahl, S. (1999). Thermophilic microorganisms: The biological background for thermophily and thermoresistance of enzymes in Thermostability of Enzymes (Gupta, M.N. editor). Springer Verlag, New Delhi, 59-60.

Steadman, B. L., Thompson, K. C., Middaugh, C. R., Matsuno, K., Vrona, S., Lawson, E. Q., \& Lewis, R. V. (1992). The effects of surface adsorpstion on the thermal stability of proteins. Biotech. and Bioeng., 40, 8-15. http://dx.doi.org/10.1002/bit.260400103

Yandri, Herasari, D., Suhartati, T., \& Hadi, S. (2008). The chemical modification of protease enzyme isolated from locale bacteria isolate, Bacillus subtillis ITBCCB148 with cyanuric chloride-polyethylenglycol. Eur. J. Sci. Res., 23(1), 177-186.

Yandri, Suhartati, T., \& Hadi, S. (2010a). Purification and Characterization of Extracellular $\alpha$-Amilase Enzyme from Locale Bacteria Isolate Bacillus subtilis ITBCCB148. Eur. J. Sci. Res., 39(1), 64-74.

Yandri, Suhartati, T., \& Hadi, S. (2010b). Immobilization of $\alpha$-Amilase Enzyme from Locale Bacteria Isolate Bacillus subtilis ITBCCB148 with diethylaminoethyl cellulose (DEAE-Cellulose). Mat. Sci. Res. Ind., 7(1), 123-128.

Yang, Z., Domach, M., Auger, R., Yang, F. X., \& Russel, A. J. (1996). Polyethylene glycol-induced stabilization of subtilisin. Enzyme and Microbial Technology, 18(2), 82-89. http://dx.doi.org/10.1016/0141-0229(95)00073-9 
Table 1 . The change of energy due to denaturation $\left(\Delta \mathrm{G}_{\mathrm{i}}\right)$, half-life $\left(\mathrm{t}_{1 / 2}\right)$, and $\mathrm{k}_{\mathrm{i}}$ values of native and immobilized enzymes

\begin{tabular}{|c|c|c|c|}
\hline Enzyme & $\mathbf{k}_{\mathbf{i}}\left(\mathbf{m i n}^{-\mathbf{1}}\right)$ & $\mathbf{t}_{\mathbf{1 / 2}} \mathbf{( \mathbf { m i n } . )}$ & $\Delta \mathbf{G}_{\mathbf{i}}\left(\mathbf{k J} \mathbf{~ m o l}^{\mathbf{- 1}}\right)$ \\
\hline Native & 0.088 & 7.875 & 99.95 \\
\hline Immobilized & 0.024 & 28.875 & 103.53 \\
\hline
\end{tabular}

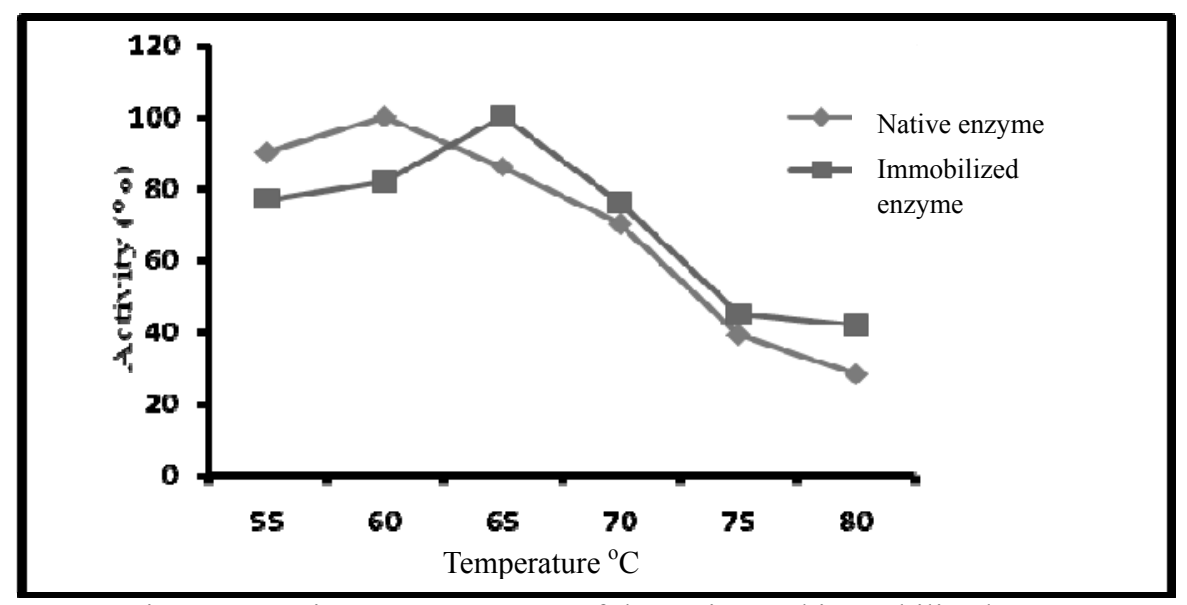

Figure 1. Optimum temperature of the native and immobilized enzymes

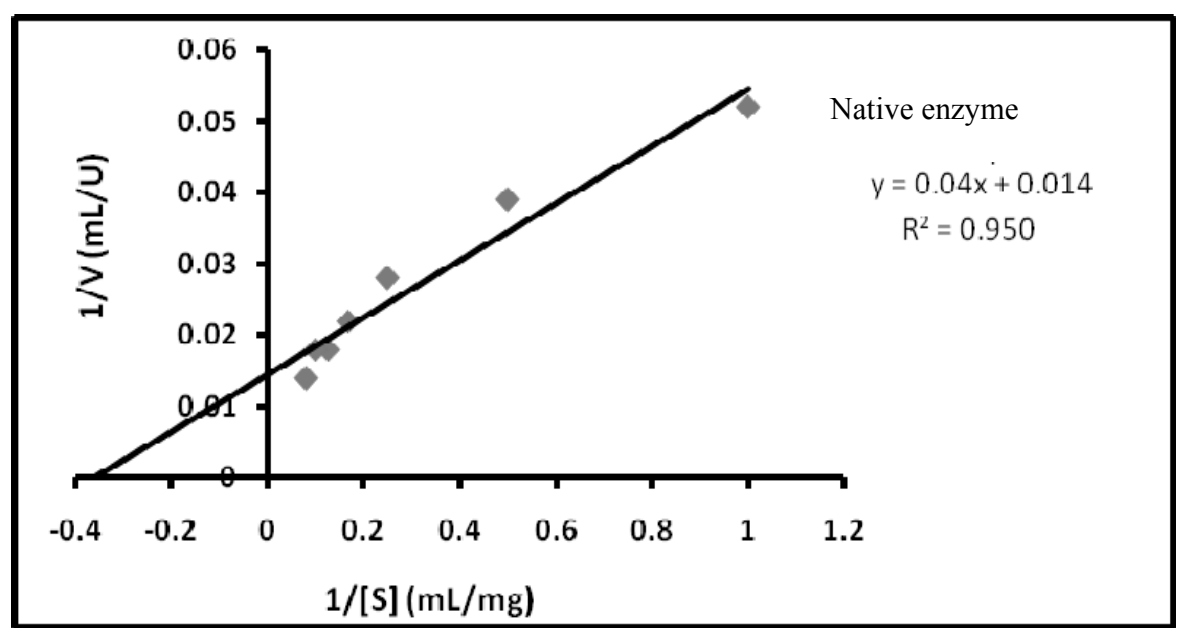

Figure 2. The graph of the Lineweaver-Burk of native $\alpha$-amylase 


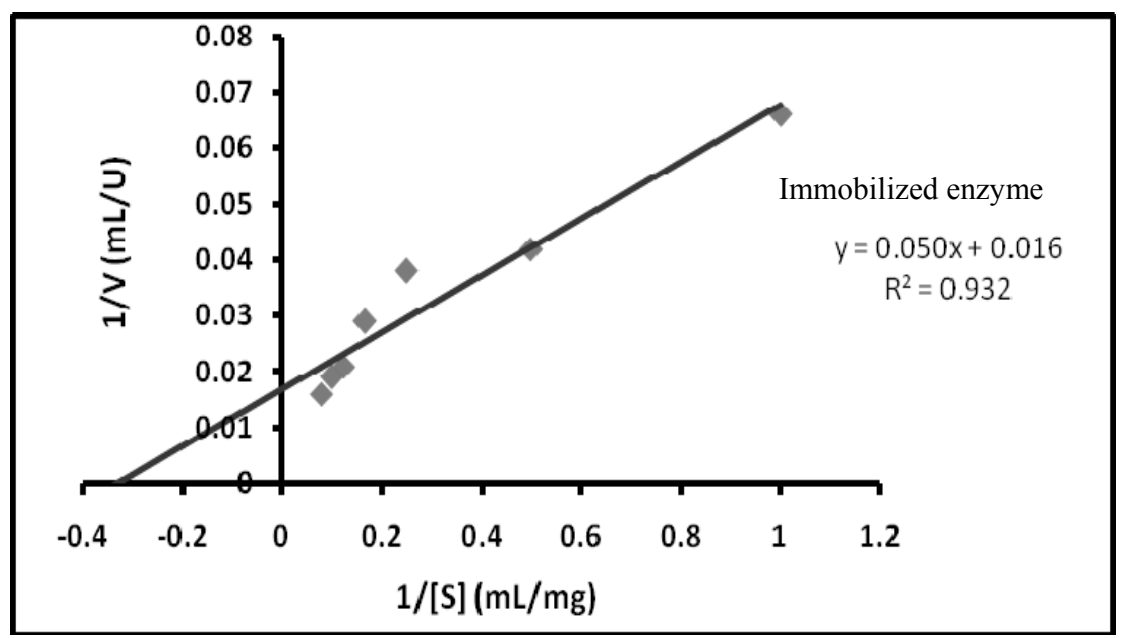

Figure 3. The graph of Grafik Lineweaver-Burk immobilized $\alpha$-amylase

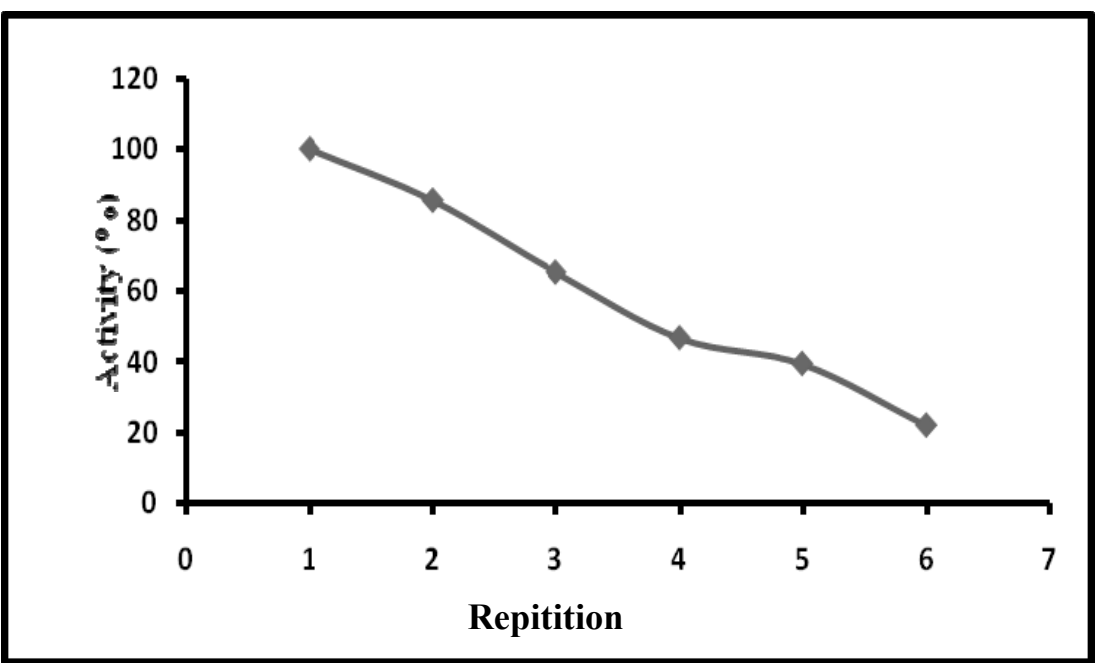

Figure 4. The use of immobilized enzyme in repeated use

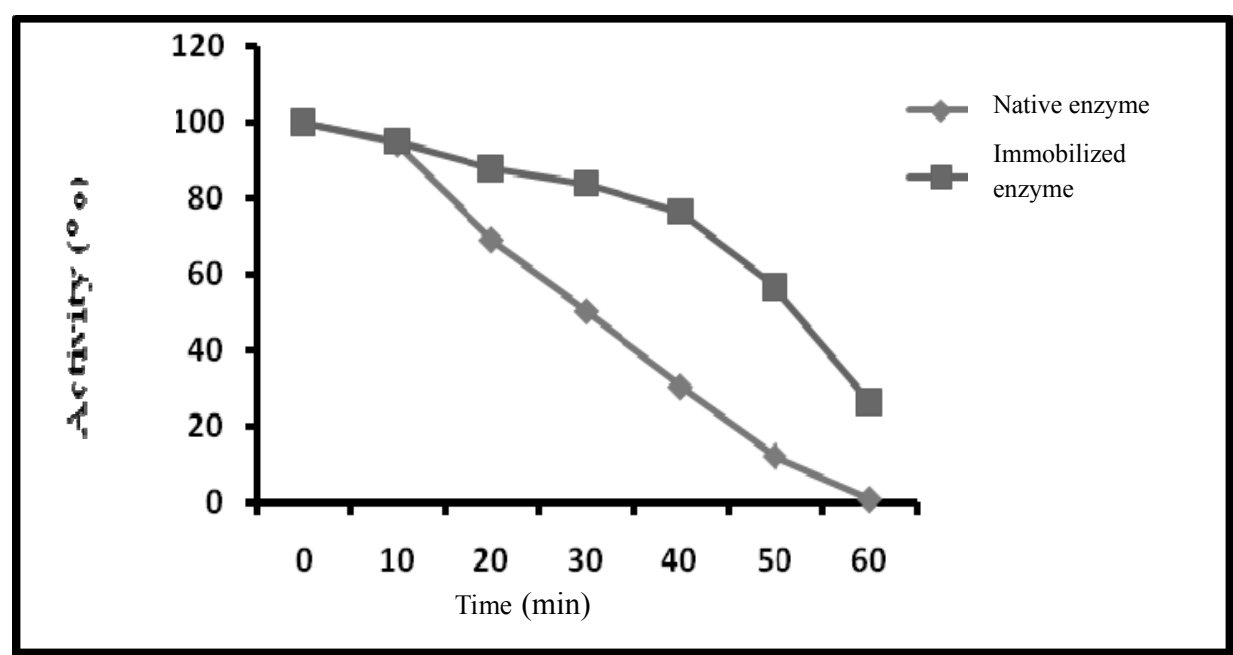

Figure 5. Thermal stability presented in graph residual activity (\%) of native and immobilized enzymes at $60{ }^{\circ} \mathrm{C}$ pH 5.5 versus time 